International Energy Agency. Energy and Climate Change: World Energy Outlook Special Report (IEA: Paris, 2015). https:/www.iea.org/publications/freepublications/publication/WEO2015SpecialReportonEnergyandClimate Change.pdf.

International Labour Organization. Decent Work in the Green Economy: Business Cases from Turkey. Ankara: ILO, 2015. http://www.ilo.org/wcmsp5/groups/public/—ed_emp/_emp_ent/documents/ publication/wcms_375698.pdf.

Kolsuz, Güneş and A. Erinç Yeldan. "Economics of Climate Change and Green Employment: A General Equilibrium Investigation for Turkey." Renewable and Sustainable Energy Reviews (in press). dx.doi.org/10.1016/j.rser.2016.12.025.

Organisation for Economic Co-operation and Development. "Revenue from Environmentally Related Taxes in Turkey." 2014. http://www.oecd.org/ctp/tax-policy/environmental-tax-profile-turkey.pdf.

Republic of Turkey. "Intended Nationally Determined Contribution." http://www4.unfccc.int/ submissions/INDC/Published\%20Documents/Turkey/1/The_INDC_of_TURKEY_v.15.19.30.pdf.

Shue, Henry. Climate Justice: Vulnerability and Protection. Oxford: Oxford University Press, 2014.

Weischer, Lutz, Jennifer Morgan, and Milap Patel. "Climate Clubs: Can Small Groups of Countries Make a Big Difference in Addressing Climate Change?" RECIEL: Review of European, Comparative \& International Environmental Law 21, no. 3 (2012): 177-192.

Yeldan, Erinç and Ebru Voyvoda. Low Carbon Development Pathways and Priorities for Turkey. İstanbul: WWF-Turkey and İstanbul Policy Center, 2015. http://www.wwf.de/fileadmin/fm-wwf/PublikationenPDF/Low_Carbon_Development_Pathways_for_Turkey_October_2015_FullStudy.pdf.

Yeldan, Erinç, Ahmet Atıl Aşıcı, Ayşen Yılmaz, Bengisu Özenç, Bora Kat, Burcu Ünüvar, Ebru Voyvoda, Ethemcan Turhan, Fatma Taşkın, Göksel N. Demirer, İsmail Yücel, Levent Kurnaz, Ömer İlter Çakmak, Mustafa Özgür Berke, Osman Balaban, Pınar İpek, Ramazan Sarı, Semra Cerit Mazlum, Sevil Acar, Uğur Soytaş, Ümit Şahin, and Vesile Kulaçoğlu. Ekonomi Politikaları Perspektifinden Iklim Değişikliği ile Mücadele. İstanbul: TÜSİA, 2016. http://tusiad.org/tr/yayinlar/raporlar/item/ download/8413_6162f22e86d7d7c12d3c5a9a77011c75.

doi: $10.1017 /$ npt.2017.20

\title{
Turkey and post-Paris climate change politics: still playing alone
}

\section{Semra Cerit Mazlum}

One of the guiding questions for this forum concerns Turkey's place in global climate politics and governance. In this contribution, I will try to answer the question of whether or not Turkey's "special circumstances" remain valid within the new climate change regime now that the Paris Agreement is in effect. The answer to this question is both yes and no. Yes because, from a legal point of view, Turkey's "special circumstances" were recognized by a Conference of Parties (COP) decision, and Turkey will continue to use this in the coming years. Yet the actual effects of

Semra Cerit Mazlum, Department of Political Science and International Relations, Marmara University, 34722, Kadıköy, İstanbul, Turkey, scmazlum@marmara.edu.tr. 
this special status are politically uncertain, if not invalid, given the new terms of reference brought by the Paris Agreement. A closer examination of the new mode of cooperation on climate change enshrined in this agreement will help illuminate why Turkey's "special" circumstances might not prove politically applicable.

The Paris Agreement itself renders ineffective the existing classification-i.e., developed vs. developing countries-based on the annexes of the UNFCCC. The agreement establishes a new architecture for the climate regime, one that combines both top-down and bottom-up elements. ${ }^{1}$ At the heart of this hybrid structure lays the pledge and review system that allows parties to the $\mathrm{UNFCCC}^{2}$ to decide upon and improve their own mitigation contributions while also keeping them accountable and ensuring the systems' integrity via a solid review process. The centerpiece of the new system is the Intended Nationally Determined Contributions (INDC), through which Parties pledged their own voluntary targets to be implemented under the terms of the agreement. Compounding this, the Paris Agreement is considered universal in participation because all Parties, both developed and developing countries alike, agree to undertake climate action in accordance with "common but differentiated responsibilities" and in light of their own respective national circumstances. ${ }^{3}$ This signals a radical shift from the Kyoto Protocol, where only the developed countries listed in the protocol's Annex B assumed binding and quantified emissions reduction (i.e., mitigation) commitments. Thus, the Paris Agreement has put an end to the bifurcated differentiation between countries based on the UNFCCC's annexes.

It should also be noted that the Paris Agreement refers to "special circumstances" with regard to those countries that are most vulnerable to the adverse effects of climate change, such as low-lying island nations; landlocked, low middle income countries; least developed countries; and so on. In short, the agreement has brought fundamental changes to the climate change regime especially concerning the flexibility introduced into the differentiation of Parties' responsibilities. The effects of these changes transcend the climate regime itself and will have ramifications on other existing and prospective environmental agreements. One recent example of this can be found in the way that the Kigali Amendment ${ }^{4}$ to the Montreal Protocol on Substances that

1 Daniel Bodansky, "The Paris Climate Change Agreement: A New Hope?" American Journal of International Law 110, no. 2 (April 2016): 288-319.

2 Hereafter, for convenience, referred to as "Parties."

3 United Nations Framework Convention on Climate Change (UNFCCC), "Adoption of the Paris Agreement," FCCC/CP/2015/L.9, December 12, 2015. https://unfccc.int/resource/docs/2015/cop21/ eng/l09.pdf.

4 See "The Kigali Amendment to the Montreal Protocol: HFC Phase-down," OzonAction Fact Sheet (2016). http://www.unep.org/ozonaction/Portals/105/documents/7809-e-Factsheet_Kigali_ Amendment_to_MP.pdf. 
Deplete the Ozone Layer ${ }^{5}$ differentiated countries more finely than simply the long-established classification of developed and developing. It is fair to say that selfdifferentiation, or modalities that provide countries with flexibility in assuming responsibilities "in the light of national circumstances," is likely to become more of a norm in the near future. Nevertheless, the Paris Agreement did not remove the UNFCCC's classification altogether, despite the fact that it does not explicitly refer to the latter's annexes. Instead, differentiation is made operational on the basis of the Paris Agreement's pillars, from mitigation to adaptation and from climate finance and transparency, thus making the agreement "a monument to differentiation," as it was called by former US Secretary of State John Kerry. ${ }^{6}$

Rather than investing all its energy and capacity into its long-standing quest for special treatment within the regime, Turkey instead needs to prepare and build an institutional capacity for implementing the Paris Agreement. Pending ratification, Turkey has yet to become one of the Parties, but once it joins, Turkey will face difficulties in complying with the pledge and review process that serves as the legally binding component of the Paris Agreement. In addition to undertaking and communicating INDCs based on its pledge and review approach, the agreement also sets up a strong and comprehensive transparency framework that builds upon the UNFCCC's existing monitoring, reporting, and reviewing mechanisms, tightening them in such a way as to require greater accountability from Parties. Turkey needs to strengthen its institutional capacity in order to ensure compliance with the reporting and reviewing obligations. Although it has considerably improved in this regard since its initial accession to the UNFCCC in 2004, Turkey's track record of reporting has been weak overall, especially as regards delays in submitting national reports. More importantly, these reports have received criticism during the review process for not being in line with the UNFCCC's reporting guidelines. One recent example of this can be found in the technical expert review of Turkey's Sixth National Communication. ${ }^{7}$ Turkey's submission has been criticized on several fronts, including a lack of clear definitions, a lack of transparency concerning the assumptions behind emissions trajectories and economy-wide scenarios, and, as already mentioned, for being inconsistent with reporting guidelines. In addition, some sectoral data are not provided in these

5 The 1988 Montreal Protocol is one of the universally ratified multilateral environmental agreements, with all 197 UN members on board, as with the UNFCCC.

6 International Institute for Sustainable Development (IISD), "Earth Negotiation Bulletin," COP 21 Final 12, no. 663 (2015). http://www.iisd.ca/download/pdf/enb12663e.pdf.

7 National communications are reports that Annex I countries periodically need to submit to the UNFCCC secretariat. See United Nations Framework Convention on Climate Change (UNFCCC), "Report of the Technical Review of the Sixth National Communication of Turkey," FCCC/IDR.6/TUR, October 21, 2016. http://unfccc.int/resource/docs/2016/idr/tur06.pdf. 
reports, on the grounds of confidentiality. As with earlier review reports, the review team recommended that Turkey "enhance transparency" and provide the "assumptions applied." 8 Similar critiques and recommendations can also be observed in the review of Turkey's joint first and second biannual report. ${ }^{9}$ One of the key reasons for Turkey's weak track record in terms of reporting is its late participation in the climate regime. Given this, staying outside the Paris Agreement would likewise result in a delay in putting into place the institutionalization of an improved monitoring and reporting structure aiming to meet the more demanding reporting and reviewing requirements.

Another issue related to Turkey's position in the climate regime is its relative loneliness in UNFCCC negotiations. As Party or negotiation groupings ${ }^{10}$ have become more important in representing countries' interests in the climate change process, Parties have come to form and cluster around new groups. Turkey, however, does not belong to any group and continues to negotiate alone, a stance that stems in part from its position in the UNFCCC process; i.e., its uniqueness through "special circumstances." Borrowing from presidential spokesperson İbrahim Kalın's description of Turkey's foreign policy, this "precious loneliness" in climate change talks leaves Turkey between a rock and a hard place in terms of making its voice heard and getting its interests represented. In the post-Paris Agreement era, any insistence on a negotiating position preoccupied with "special circumstances" would cost Turkey, effectively forcing it to remain alone. But Turkey's loneliness is not limited to formal negotiating platforms where intergovernmental affairs are debated. Although states are still the principal actors in making final decisions, the constellation of actors in global climate governance is rapidly transforming, with non-state actors-including businesses, sub-national authorities, environmental organizations, and social movementsbecoming more active and influential. Hence, it is important for states to work with non-state actors, and yet Turkey has thus far been unsuccessful in engaging with non-state actors both at home and on the international level.

Moreover, Turkey needs to realize the changing patterns of climate change politics. After the utter failure to strike a global deal at the 2009 Copenhagen Summit (COP 15), Parties began seeking new platforms through which to formulate effective climate policies, pointing out how difficult it was to arrive at decisive action under the UNFCCC process owing to the plethora of interests involved. Notions of "minilateralism" or "climate clubs" have been

8 Ibid.

9 United Nations Framework Convention on Climate Change (UNFCCC), "Report of the Technical Review of a Joint First and Second Biennial Report of Turkey," FCCC/TRR.2/TUR, October 14, 2016. http://unfccc.int/resource/docs/2016/trr/tur.pdf.

10 See also Murat Türkeş's contribution in this roundtable. 
promoted as alternatives to the UNFCCC for achieving workable solutions for global climate change. ${ }^{11}$ This bottom-up approach to policy making paved the way for the use of other platforms in parallel with formal negotiations under the UNFCCC. The Group of Twenty (G20), among others, was the most prominent candidate to take the lead of climate talks insofar as it consists primarily of major greenhouse gas emitters. For the sake of securing an agreement at the 2015 Paris Summit (COP 21), and based on the bottom-up approach endorsed, Parties used multiple fora to devise the Paris Agreement. Thus, the general outlook of the agreement was discussed and took shape during these informal negotiations. In this changing landscape of climate talks, Turkey gained a rare opportunity inasmuch as it held the G20 presidency in 2015, just before the Paris Summit. The G20 presidency gave Turkey a chance to break away from its invisibility in global climate politics and play an active role in influencing the powerful group's climate agenda, thereby sending a strong message at COP 21 . What is more, the presidency also earned Turkey an open invitation to all informal talks in the run-up to COP 21, including informal ministerial meetings and the Major Economies Forum on Energy and Climate. ${ }^{12}$ With the ascendancy of the G20 in global climate politics, Parties from both developed and developing countries looked to Turkey to hear its views on climate change. Turkey could have taken advantage of this opportunity not only to further its own agenda, but also to bring to the table the interests of climate-vulnerable countries, including the least developed countries, which Turkey particularly focuses on in channeling its foreign aid through the Turkish International Cooperation and Coordination Agency (Türk İşbirliği ve Koordinasyon Ajansı, TİKA). However, Turkey's focus on issues other than climate change, together with unwillingness on the part of certain G20 members, ultimately made this rare juncture a missed opportunity for the country to project its climate diplomacy.

Understanding Turkey's place in the climate regime also requires paying attention to emerging dynamics in global climate governance, which is exhibiting

11 Robert Falkner, "A Minilateral Solution for Global Climate Change? On Bargaining Efficiency, Club Benefits, and International Legitimacy," Perspectives on Politics 14, no. 1 (2016): 87-101; Robyn Eckersley, "Moving Forward in the Climate Negotiations: Multilateralism or Minilateralism?" Global Environmental Politics 12, no. 2 (2012): 24-42; and Robert O. Keohane and David G. Victor, "Cooperation and Discord in Global Climate Policy," Nature Climate Change 6, no. 6 (2016): 570-575.

12 The Major Economies Forum on Energy and Climate is an initiative of the presidency of Barack Obama that brought together 17 major economies to reach an overarching climate deal. The countries involved are Australia, Brazil, Canada, China, the EU, France, Germany, India, Indonesia, Italy, Japan, South Korea, Mexico, Russia, South Africa, the UK, and the USA.

13 Megan Darby, "G20 Leaders Disappoint Climate Campaigners with Weak Statement," Climate Home, November 16, 2015. http://www.climatechangenews.com/2015/11/16/g20-leaders-disappointclimate-campaigners-with-weak-statement/. 
an increasing level of institutional fragmentation. ${ }^{14}$ This is, to some extent, a necessary corollary to the fact that climate action occurs across a range of levels, from the local to the global, and is undertaken by a diverse set of actors, ranging from states to non-state actors. Remarkably, cities and various levels of sub-national governments have also come to take a leading part in climate action, both in their own territories and as a part of transnational networks. This multiplicity of action taking place outside the scope of the UNFCCC paradoxically reflects both disappointment in the slow progress of international negotiations and the momentum created in the run-up to COP 21. Various explanations can be offered for the rise of polycentric climate governance as well as for the challenge that this institutional complexity poses to coordinated climate action. However, given the focus here, it is especially important to note the opportunities this dynamic presents to Turkey, which is thereby given the chance to take part in global cooperative efforts aimed at curbing climate change. Turkey needs to explore options to either take its own initiative or to join existing groups with relevance to its own priorities. Such platforms or climate clubs not only catalyze countries' stronger integration into global efforts, but also provide partners the opportunity to learn about and innovate environmental policy. ${ }^{15}$

Lastly, I would like to turn to an emerging issue in global climate politics, one related to the long-term temperature target of the Paris Agreement. The agreement commits Parties to hold the global average temperature increase to "well below 2 degress Celsius above pre-industrial levels," and sets an aspirational goal to pursue efforts to keep the increase to $1.5^{\circ} \mathrm{C}$, which is deemed vital for certain low-lying island nations. Despite being an important achievement from a climate justice perspective, the $1.5^{\circ} \mathrm{C}$ target will be difficult to achieve without drastic collective emissions reduction measures. Given that countries' current emissions reduction pledges, even if fully implemented, would commit the world to a 2.6 to $3.7^{\circ} \mathrm{C}$ warmer world, $1.5^{\circ} \mathrm{C}$ seems politically implausible, if not technically infeasible. ${ }^{16}$ Climate modeling studies project that even a $2^{\circ} \mathrm{C}$ target may only be achievable through extensive use of so-called "negative emission technologies," which refers to a large-scale uptake of carbon dioxide removal technologies. ${ }^{17}$ Some studies even assume that staying at $1.5^{\circ} \mathrm{C}$ would require deployment of science fiction-like geoengineering

14 Fariborz Zelli and Harro van Asselt, "Fragmentation," in Research Handbook on Climate Governance, ed. Karin Bäckstrand and Eva Lövbrand (Cheltenham: Edward Elgar, 2015): 121-131.

15 Lukas Hermwille, Wolfgang Obergassel, Hermann E. Ott, and Christiane Beuermann. "UNFCCC before and after Paris-what's necessary for an effective climate regime?." Climate Policy (2015): 1-21.

16 Joeri Rogelj, Michel den Elzen, Niklas Höhne et al., "Paris Agreement Climate Proposals Need a Boost to Keep Warming well below $2^{\circ} \mathrm{C}^{\prime}$ "Nature 534, no. 7609 (2016): 631-639.

17 These are also referred to as CCS (carbon capture and storage) and BECCS (bio-energy with carbon capture and storage) technologies. 
technologies, notably solar geoengineering. In the face of the inadequacy of existing global policies to meet the goal of the Paris Agreement, the deployment and governance of negative emissions options have been attracting growing scholarly attention. While some authors argue that the Paris Agreement itself brought about this debate through its ambitious $1.5^{\circ} \mathrm{C}$ target, ${ }^{18}$ there remain serious uncertainties concerning these largely unproven, risky, and controversial technologies. Deployment of such technologies at the scale required to meet the target of the Paris Agreement would also inevitably come to involve ethical and political issues. For example, BECCS (bio-energy with carbon capture and storage) technologies require large amounts of land to grow industrial tree plantations, which would in turn result in competition with food production on land and water, thereby further entrenching inequalities for the poor. ${ }^{19}$ Ultimately, a new climate diplomacy debate is likely to emerge in connection with such issues as these. No matter what vague reference the Paris Agreement might make to climate justice, we are likely to continue to face new ecological and economic injustices in areas such as food, energy, and water, and so social scientists must look at climate change from this viewpoint as well. This will require us to go beyond Turkey and look at what is happening in the wider world.

\section{References}

Barrett, Scott and Juan Moreno-Cruz. "The Alternatives to Unconstrained Climate Change: Emission Reductions versus Carbon and Solar Geoengineering." In Towards a Workable and Effective Climate Regime. Edited by Scott Barrett, Carlo Carraro, and Jaime de Melo. London and Clermont-Ferrand: CEPR Press and Ferdi, 2015. 353-365.

Bodansky, Daniel. "The Paris Climate Change Agreement: A New Hope?" American Journal of International Law 110, no. 2 (April 2016): 288-319.

Darby, Megan. "G20 Leaders Disappoint Climate Campaigners with Weak Statement." Climate Home. November 16, 2015. http://www.climatechangenews.com/2015/11/16/g20-leaders-disappointclimate-campaigners-with-weak-statement/.

Eckersley, Robyn. "Moving Forward in the Climate Negotiations: Multilateralism or Minilateralism?" Global Environmental Politics 12, no. 2 (2012): 24-42.

Falkner, Robert. "A Minilateral Solution for Global Climate Change? On Bargaining Efficiency, Club Benefits, and International Legitimacy." Perspectives on Politics 14, no. 1 (2016): 87-101.

Hermwille, Lukas, Wolfgang Obergassel, Hermann E. Ott, and Christiane Beuermann. "UNFCCC before and after Paris-what's necessary for an effective climate regime?." Climate Policy (2015): 1-21. http://dx.doi.org/10.1080/14693062.2015.1115231.

Horton, Joshua B., David W. Keith, and Matthias Honegger. "Implications of the Paris Agreement for Carbon Dioxide Removal and Solar Geoengineering." Policy brief. Harvard Project on Climate

18 Andy Parker and Oliver Geden, "No Fudging on Geoengineering," Nature Geoscience 9, no. 12 (2016): 859-860 and Joshua B. Horton, David W. Keith, and Matthias Honegger, "Implications of the Paris Agreement for Carbon Dioxide Removal and Solar Geoengineering," Policy brief, Harvard Project on Climate Agreements, Belfer Center, 2016. http://www.belfercenter.org/sites/default/files/legacy/files/ 160700_horton-keith-honegger_vp2.pdf.

19 Richard Martin, "The Dubious Promise of Bioenergy Plus Carbon Capture," MIT Technology Review, January 8, 2016. https://www.technologyreview.com/s/544736/the-dubious-promise-of-bioenergyplus-carbon-capture/. 
Agreements, Belfer Center, 2016. http://www.belfercenter.org/sites/default/files/legacy/files/ 160700_horton-keith-honegger_vp2.pdf.

International Institute for Sustainable Development (IISD). "Earth Negotiation Bulletin." COP 21 Final 12, no. 663 (2015). http://www.iisd.ca/download/pdf/enb12663e.pdf.

Keohane, Robert O. and David G. Victor. "Cooperation and Discord in Global Climate Policy." Nature Climate Change 6, no. 6 (2016): 570-575.

Martin, Richard. "The Dubious Promise of Bioenergy Plus Carbon Capture." MIT Technology Review. January 8, 2016. https://www.technologyreview.com/s/544736/the-dubious-promise-of-bioenergyplus-carbon-capture/.

Parker, Andy and Oliver Geden. "No Fudging on Geoengineering." Nature Geoscience 9, no. 12 (2016): 859-860.

Rogelj, Joeri, Michel den Elzen, Niklas Höhne, Taryn Fransen, Hanna Fekete, Harald Winkler, Roberto Schaeffer, Fu Sha, Keywan Riahi, and Malte Meinshausen. "Paris Agreement Climate Proposals Need a Boost to Keep Warming well below 2 C." Nature 534, no. 7609 (2016): 631-639.

"The Kigali Amendment to the Montreal Protocol: HFC Phase-down." OzonAction Fact Sheet, 2016. http://www.unep.org/ozonaction/Portals/105/documents/7809-e-Factsheet_Kigali_Amendment_to_ MP.pdf.

United Nations Framework Convention on Climate Change (UNFCCC). "Adoption of the Paris Agreement." FCCC/CP/2015/L.9. December 12, 2015. https://unfccc.int/resource/docs/2015/cop21/ eng/l09.pdf.

. "Report of the Technical Review of the Sixth National Communication of Turkey." FCCC/IDR.6/ TUR. October 21, 2016. http://unfccc.int/resource/docs/2016/idr/tur06.pdf.

. "Report of the Technical Review of a Joint First and Second Biennial Report of Turkey." FCCC/ TRR.2/TUR. October 14, 2016. http://unfccc.int/resource/docs/2016/trr/tur.pdf.

WBGU - German Advisory Council on Global Change. "Development and Justice through Transformation: The Four Big 'I's." Special Report. Berlin: WBGU, 2016.

Zelli, Fariborz and Harro van Asselt. "Fragmentation." In Research Handbook on Climate Governance. Edited by Karin Bäckstrand and Eva Lövbrand. Cheltenham: Edward Elgar, 2015. 121-131.

doi: $10.1017 / n p t .2017 .21$

\section{Right here, right now: a call for} engaged scholarship on climate justice in Turkey

\section{Ethemcan Turhan}

There are a few different issues that I would like to address and unfortunately not all of them can be treated in depth here; hopefully, though, they can open up some new discussions. Such beginnings, particularly if they can pave the way for more social science engagement with climate change in Turkey, might also

Ethemcan Turhan, Environmental Humanities Lab, KTH Royal Institute of Technology, SE-100 44, Stockholm, Sweden, ethemcan@kth.se. 